Business \& Entrepreneurship Journal, Vol. 11, No. 1, 2022, 1-25

ISSN: 2241-3022 (print version), 2241-312X(online)

https://doi.org/10.47260/bej/1111

Scientific Press International Limited

\title{
Success Factors of Corporate Accelerators
}

\author{
Ton Guardiet ${ }^{1}$, Alexander Oreschenko ${ }^{2}$ and Hendrick Wawers ${ }^{3}$
}

\begin{abstract}
Corporate accelerators have become an important form of corporate-start-up collaboration. According to [1] mm1 (consultancy for Connected Business), twothirds of all DAX 30 companies in Germany engaged with start-ups via an accelerator in the year 2020. Despite the clear importance of this phenomenon, there is still a lack of understanding of the concrete factors that determine their success. Corporate accelerators can be designed in different ways but business executives are still in the dark about the consequences of these design decisions on the performance. The aim of present study is to determine success factors of a selected set of corporate accelerators based on qualitative data. A database of 109 corporate accelerators was collected from which all Germany based programs (28) were analysed in greater detail regarding their performance and program design. Hereby, the study tests the statistical relevance of 14 potential success factors identified via literature review conducted on the matter. The results show that especially five factors have a significant positive correlation to a corporate accelerators success:

The existence of corporate partners.

A demanding selection process that contains selection days for shortlisted start-ups. A larger amount of start-ups per batch.

The obligation for start-ups to be physically present in the facilities for the time of the program (Pre Covid19).

The incorporation of metrics to track the progress of participating start-ups.
\end{abstract}

JEL classification numbers: $\mathrm{O} 31$.

Keywords: Acceleration programs, Corporate acceleration, Corporate entrepreneurship, start-ups, Corporate incubators.

${ }^{1}$ Universitat Internacional de Catalunya, Barcelona, Spain.

2 Universitat Ramon Llull, Barcelona, Spain.

${ }^{3}$ Universitat Ramon Llull, Barcelona, Spain.

https://.orcid.org/0000-0002-2159-216X

Article Info: Received: December 18, 2022. Revised: January 19, 2022.

Published online: January 25, 2022. 


\section{Introduction}

In any economy and for any corporation, growth is an essential factor. As already stated by the economist [2], the growth (and thereby the survival) of any company depends on its innovation. In times of growing market pressure and increasing market density, corporations are more and more in need of constant innovations. However, they still struggle to foster disruptive innovation within their company borders even if it's importance is evident. One of the forms to of innovation which gained traction in the recent years is open innovation. Especially the collaboration with start-ups progressively gains importance [3]. According to a report from INSEAD and 500Startups, at least 50\% of the world's largest 500 companies had some sort of start-up engagement program [4]. One form of corporate start-up collaboration that combines the resources of large firms in financial aspect, brand reputation and market position with the creativity of start-ups is corporate accelerator program (CA). To understand what corporate accelerators are it is first noteworthy to talk about independent accelerators. Usually those are programs with 3-6 months duration that help new ventures in early stages of development by providing support services such as office spaces, coaching and mentoring, small amount of financial support and set of education programs [5]. The term was first used to describe Colorado Venture Centres in 2001. Although the model was invented even before, the origins came around 1989 as Boulder Technology Incubator was founded and used to support start-ups in a very similar way to today's accelerators. Finally, in 2005 Y Combinator was set up by Paul Graham, around the same time more companies started to emerge all around the US and after some years Europe and Asia started to implement the same model to support their ecosystems. The difference of corporate accelerator from their independent peers is that they are founded or sponsored by corporate entities whose primary business is not related to working with start-ups. The accelerator gives parent company the possibility to bring state of-the-art knowledge and ideas into the company and increase the likelihood of successful innovative growth. From the perspective of entrepreneurship ecosystem, CAs (just as their independent counterparts) close the gap between angel and VC investments [6]. Consequently, their number is steadily and quickly increasing [7].

In his global database of corporate accelerator programs, [6] lists $71 \mathrm{CA}$ programs across 25 countries. Hereby, the CA trend not only limited to the high technology sector but spreads across industries like healthcare (Bayer), insurance (Allianz), entertainment (Disney) or consumer goods (Coca-Cola) [8]. According to [9], CAs raise an average of \$2-5 million per year. Only Microsoft accelerator on its own accelerated 647 start-ups over its lifetime so far and raised a total of $\$ 3$ billion [10]. Meanwhile, "little research has explored whether these programs are effective, which ones are more effective and what might drive results" [11], especially regarding Cas [10]. This is mainly due to the novelty of the accelerator appearance [6]. It is too early to evaluate the accelerator programs' outcomes and there is a lack of in-depth data sources which is why only a limited amount of studies researched 
the success factors of accelerators, and even less those of CAs specifically.

Despite the growing importance, existing literature on corporate accelerators merely provides a very narrow and holistic understanding of the topic. The majority of studies examines either independent [12], [13], or public programs [14]. So far, only few papers address corporate acceleration directly were published in peer-reviewed journals [7], [6], [8], [3], [15] and [10]. Out of these, the majority aims to define and classify CAs, success factors only play a minor role in the research. This paper aims to close the research gap by investigating success drivers of corporate accelerators, in detail the following research question: Which characteristics define a successful corporate acceleration program?

The underlying goal behind the research questions is to find a list of (in the best case prioritized) success factors that influence the outcome of a general CA's performance. Due to the growing number of CAs in the market, many warn of a bubble of accelerators that will lead to a shortage of essential resources (mentors and managers e.g.). As a result, the programs that are not properly set up and are less effective will be combed out.

The importance of this study is clear for any company that is looking for new ways of innovating and collaborating with startups. With very competitive landscape that current corporates find themselves in, dedicating resources for innovation is not always top priority as many managers see it as not crucial part of their business. Consequently to receive necessary budget CA managers must show high effectiveness and positive return on investment which is key to outperform the competition and drive the company forward. This study aims to guide corporate accelerators managers in the process of improving their performance by understanding the success drivers behind their business model from scientific point of view. To give even more detailed insights, the difference of success factors of different types of CAs is analysed. Based on the outcome of the research, the managers can allocate their program to a typology and compare the success drivers of common peers to their own business.

\section{Method}

Due to the newness of the phenomenon, data collection on success factors of CAs is rare. The lack of consideration of CA programs in existing research calls for a detailed analysis and theoretical integration into the academic world.

\subsection{Data composition}

In order to answer the research question, a database of corporate acceleration programs was created, based on Heinemann's original database of 71 CAs from the year 2015, we have introduced data about new CAs that have launched since and enhanced the previous data to reach 109 CA mostly from developed countries. Data sources were websites of the examined CAs, online data banks, newspaper archives and thematically similar scientific works. The starting point for each CA analysis was the respective website of a CA program, from where missing information was 
supplemented by data from online data banks and newspaper articles. The descriptive analysis of the global CA database was elaborated to ensure representative sample of the industry. Some of the aspects were: the average CA was launched in 2015 (28\% of the sample) in the USA (22\%), It has only one branch $(67 \%)$ that is in the same country as its mother company's HQ (86\%). The average focus of the program is related to its mother company's industry $(71 \%)$, which is either the Information (33\%), Manufacturing (23\%) or Finance and Insurance (17\%) sector.

Regarding program design, the average corporate accelerator has:

1. Program duration between 3-6 months ( $81 \%)$, with 3 months is the most likely option (44\%).

2. Usually provide funding (65\%) between $€ 20-50 \mathrm{~K}$ (37\% of those that give funding).

3. Most take no equity in return (46\%), if it does take equity than an equity stake of $6 \%$ (35\% of those that take equity).

4. Offers its program in a yearly interval (26\%)

5. Takes in an average of 8,9 participating startups per batch into its program

6. Does not have an independent accelerator as a partner (66\%), if it does have an independent accelerator partner then it will probably be Techstars $(41 \%)$ or PlugAndPlay (14\%)

\subsection{Methodology of data analysis}

From the global database, 28 corporate accelerators were shortlisted and analysed in greater detail. The selected accelerators were all based in Germany as this is the most advanced European startup and innovation ecosystem. Moreover, having all CA from one country enables the harmonization of the sample as all would be operating within the same legal and financial framework which makes direct comparison possible without the need to apply additional transformation adjustments to improve the quality of the data. Additional reason behind selecting CA from the same country was to compare with greater precision all the participants and their characteristics. The sample of 28 was taken from different industries to make it as representative as possible of the real German economy.

Qualitative information was encoded and categorized to allow a quantitative analysis of the data with the help of statistical models that test the hypothesizes and explain the observations. The quantitative analysis of the data consisted of three major steps. First, the $28 \mathrm{CAs}$ that were part of the detailed sample analysis were classified (creating an additional database of 952 startups that participated in their programs since the inception and additional analysis of their performance), subsequently, their success was evaluated to then finally assess whether certain characteristics of the CA's design significantly predict whether its performance is successful or not. 


\subsection{Definition of success criteria}

Table 1: Overview of success criteria in existing literature

\begin{tabular}{|c|c|c|c|c|c|c|}
\hline & $\begin{array}{c}\text { Hoffman and } \\
\text { Radojevich } \\
\text { Kelley (2012) }\end{array}$ & $\begin{array}{c}\text { Smith and } \\
\text { Hannigan } \\
\mathbf{( 2 0 1 5 )}\end{array}$ & $\begin{array}{c}\text { Hallen, } \\
\text { Cohen } \\
\text { (2019) }\end{array}$ & $\begin{array}{c}\text { Baird, } \\
\text { Bingham } \\
\text { Cohen } \\
\text { Bowles } \\
\text { and } \\
\text { Lall }\end{array}$ & $\begin{array}{c}\text { Kohler } \\
\text { (2013) }\end{array}$ & No16) \\
\hline Number of graduates & No & No & Yes & No & No \\
\hline $\begin{array}{c}\text { Follow-up } \\
\text { investment }\end{array}$ & Yes & Yes & Yes & Yes & Yes & No \\
\hline $\begin{array}{c}\text { Graduate's company } \\
\text { value }\end{array}$ & No & No & Yes & No & No & No \\
\hline $\begin{array}{c}\text { Graduate's survival } \\
\text { rate }\end{array}$ & Yes & No & Yes & No & Yes & No \\
\hline $\begin{array}{c}\text { Satistaction of } \\
\text { graduates }\end{array}$ & No & No & Yes & No & No & No \\
\hline Profitability rate & No & No & No & No & Yes & No \\
\hline Cooperation rate & No & No & No & No & No & Yes \\
\hline Number of exits & No & Yes & No & Yes & No & No \\
\hline $\begin{array}{c}\text { Major follow-up } \\
\text { investment }\end{array}$ & No & No & No & No & Yes & No \\
\hline $\begin{array}{c}\text { Gained costumer } \\
\text { traction }\end{array}$ & No & No & No & Yes & No & No \\
\hline $\begin{array}{c}\text { Employee growth } \\
\text { No }\end{array}$ & No & No & Yes & No & No \\
\hline
\end{tabular}

Out of all the possibilities given in the overview of Table 1, the success criteria to evaluate the CAs of this sample analysis were chosen for the following reasons:

a) The relevance in existing literature: success criteria that were used in various previous studies were also taken over in this study. As a result, the success criteria "Follow-Up Investment" and "Number of Exits" were chosen as success criteria.

b) The fit to this specific study: CAs typically focus on early-stage start-ups. In this paper, the profitability of the ventures is usually not of the highest importance. As a result, the total number of graduates just like the overall operation time in years gives a hint about a CA's success.

c) The availability of the needed data: the sources of information for this study were exclusively publicly available data. As a result, the success criteria "Satisfaction of Graduates", "Gained customer traction" and "Employee growth" was excluded due to missing information.

In order to calculate the respective numbers for each corporate accelerator, all alumni start-ups from all previous batches were listed in a separate database. Information about the alumni start-ups was taken from the websites or from old 
newspaper articles reporting on the start of a new batch. The final list consisted of a total of 952 start-ups and the main qualifications looked into were:

- Operating status (survival rate)

- Whether companies received follow-up funding (follow-up investment rate)

- Follow up funding amount (Major follow-up investment rate and average company value)

- Whether they started a cooperation with the CA's mother company (cooperation rate)

- Whether they were acquired (number of exits)

Table 2 gives an overview, for which thresholds the respective success criteria were considered as successful, moderate or not successful. The figures themselves originated from the empirical studies available and mentioned beforehand as well as general assumptions regarding the success of every particular program.

Table 2: Thresholds to define successful, moderate and not successful Corporate Accelerators

\begin{tabular}{|c|c|c|c|}
\hline & Success & Moderate & No success \\
\hline Enterprise survival rate & $>=90 \%$ & $>=80 \%$ & $<80 \%$ \\
\hline Enterprise follow-up inv. rate & $>=30 \%$ & $>=20 \%$ & $<20 \%$ \\
\hline Major follow-up inv. rate & $>=10 \%$ & $>=5 \%$ & $<5 \%$ \\
\hline Enterprise cooperation rate & $>=20 \%$ & $>=10 \%$ & $<10 \%$ \\
\hline Total money raised by alumni (in $\mathrm{M} €$ ) & $>=€ 50 \mathrm{M}$ & $>=€ 5 \mathrm{M}$ & $<€ 5 \mathrm{M}$ \\
\hline Money/ Startup & $>=€ 0,5 \mathrm{M}$ & $>=€ 0,1 \mathrm{M}$ & $<=€ 0,1 \mathrm{M}$ \\
\hline Number of exits & $>=0,5$ & $>=1$ & $<=1$ \\
\hline
\end{tabular}

\subsection{Derivation of success drivers}

Existing literature review, in combination with interviews and other data sources resulted in elaboration of 14 potential success drivers which were classified as hypothesis, listed from $\mathrm{H} 1$ to H14. Table 3 gives an overview of the applied tests used to analyse the significance and correlation of the different success driver categories. They hypothesis tested against null hypothesis are explained in the Hypothesis column.

As not all data types are similar, multiple significance distributions were used in order to achieve highest level of precision. For categorical datasets Chi Square distribution was used, for continuous dataset with intervals or scale simple logistic regression would provide most accurate results. On the other hand, correlation was calculated using three main distributions, Phi, Cramer's V and Point-Biserial Correlation by Pearson. 
Table 3: Overview of test type per tested success driver category

\begin{tabular}{|c|c|c|c|c|c|}
\hline Variable type & $\begin{array}{c}\text { Tested } \\
\text { Success } \\
\text { Driver } \\
\end{array}$ & Hypothesis & Data Type & $\begin{array}{c}\text { Significance } \\
\text { test }\end{array}$ & $\begin{array}{c}\text { Correlation } \\
\text { test }\end{array}$ \\
\hline Dependent & Successful & - & $\begin{array}{c}\text { Categorical } \\
\text { (dichotomous) }\end{array}$ & - & - \\
\hline Independent & $\begin{array}{l}\text { Prior } \\
\text { knowledge } \\
\text { (years in } \\
\text { operation) }\end{array}$ & $\begin{array}{c}\mathrm{H} 0 \text { (/ H1): There is } \\
\text { independence (/a relation) } \\
\text { between the years of prior } \\
\text { knowledge and a CA's } \\
\text { success } \\
\end{array}$ & Continuous (scale) & $\begin{array}{c}\text { Simple } \\
\text { logistic } \\
\text { regression }\end{array}$ & $\begin{array}{c}\text { Point-Biserial } \\
\text { Correlation by } \\
\text { Pearson }\end{array}$ \\
\hline Independent & $\begin{array}{c}\text { Clear } \\
\text { vertical? }\end{array}$ & $\begin{array}{l}\mathrm{H} 0 \text { (/ H2): It is not (/ it is) a } \\
\text { predictor of success whether } \\
\text { the CAs has a clear vertical } \\
\text { or not }\end{array}$ & Categorical & Chi-Square & Phi \\
\hline Independent & $\begin{array}{l}\text { Program } \\
\text { duration }\end{array}$ & $\begin{array}{c}\text { H0 (/ H3): There is } \\
\text { independence (/ a relation) } \\
\text { between the program } \\
\text { duration and a CA's success }\end{array}$ & Continuous (interval) & $\begin{array}{c}\text { Simple } \\
\text { logistic } \\
\text { regression }\end{array}$ & $\begin{array}{c}\text { Point-Biserial } \\
\text { Correlation by } \\
\text { Pearson } \\
\end{array}$ \\
\hline Independent & $\begin{array}{l}\text { Portfolio } \\
\text { size }\end{array}$ & $\begin{array}{c}\text { H0 (/ H4): There is } \\
\text { independence (/ a relation) } \\
\text { between the portfolio size } \\
\text { and a CA's success }\end{array}$ & Continuous (interval) & $\begin{array}{l}\text { Simple } \\
\text { logistic } \\
\text { regression }\end{array}$ & $\begin{array}{c}\text { Point-Biserial } \\
\text { Correlation by } \\
\text { Pearson }\end{array}$ \\
\hline Independent & $\begin{array}{c}\text { Selection } \\
\text { selectivity }\end{array}$ & $\begin{array}{c}\text { H0 (/ H5): There is } \\
\text { independence (/ a relation) } \\
\text { between the selection } \\
\text { selectivity and a CA's } \\
\text { success }\end{array}$ & Continuous (scale) & $\begin{array}{l}\text { Simple } \\
\text { logistic } \\
\text { regression } \\
\end{array}$ & $\begin{array}{c}\text { Point-Biserial } \\
\text { Correlation by } \\
\text { Pearson } \\
\end{array}$ \\
\hline Independent & $\begin{array}{l}\text { Selection } \\
\text { Process } \\
\text { Type } \\
\end{array}$ & $\begin{array}{c}\mathrm{H} 0 \text { (/ H6): There is } \\
\text { independence (/ a relation) } \\
\text { between the selection } \\
\text { process type and a CA's } \\
\text { success }\end{array}$ & Categorical & Chi-Square & Cramer's V \\
\hline Independent & $\begin{array}{l}\text { CA's } \\
\text { Team } \\
\text { Compositi } \\
\text { on }\end{array}$ & $\begin{array}{c}\mathrm{H} 0 \text { (/ H7): There is } \\
\text { independence (/ a relation) } \\
\text { between the CA's team } \\
\text { composition and a CA's } \\
\text { success }\end{array}$ & Categorical & Chi-Square & Cramer's V \\
\hline Independent & $\begin{array}{c}\text { Incorporat } \\
\text { ed metrics? }\end{array}$ & $\begin{array}{l}\mathrm{H} 0 \text { (/ H8): It is not (/ it is) a } \\
\text { predictor of success whether } \\
\text { the CA uses success metrics } \\
\text { or not }\end{array}$ & Categorical & Chi-Square & Phi \\
\hline Independent & $\begin{array}{c}\text { Support } \\
\text { from top } \\
\text { manageme } \\
\text { nt? }\end{array}$ & $\begin{array}{l}\mathrm{H} 0 \text { (/ H9): It is not (/ it is) a } \\
\text { predictor of success whether } \\
\text { the CA is supported from the } \\
\text { mother company's top } \\
\text { management or not. }\end{array}$ & Categorical & Chi-Square & Phi \\
\hline Independent & $\begin{array}{c}\text { Corporate } \\
\text { partner? }\end{array}$ & $\begin{array}{l}\mathrm{H} 0 \text { (/ H10): It is not (/ it is) a } \\
\text { predictor of success whether } \\
\text { the CA cooperates with } \\
\text { other corporations or not }\end{array}$ & Categorical & Chi-Square & Phi \\
\hline
\end{tabular}




\begin{tabular}{|c|c|c|c|c|c|}
\hline Independent & $\begin{array}{c}\text { Scouting } \\
\text { team? }\end{array}$ & $\begin{array}{c}\text { H0 (/ H11): There is } \\
\text { independence (/ a relation) } \\
\text { between the existence of a } \\
\text { scouting team that actively } \\
\text { looks for start-ups and a } \\
\text { CA's success }\end{array}$ & Categorical & Chi-Square & Cramer's V \\
\hline Independent & $\begin{array}{c}\text { Mandatory } \\
\text { physical } \\
\text { presence? }\end{array}$ & $\begin{array}{l}\mathrm{H} 0 \text { (/ H12): It is not (/ it is) a } \\
\text { predictor of success whether } \\
\text { physical presence is } \\
\text { mandatory in the program or } \\
\text { not }\end{array}$ & Categorical & Chi-Square & Cramer's V \\
\hline Independent & $\begin{array}{c}\text { Size of } \\
\text { mentor } \\
\text { pool }\end{array}$ & $\begin{array}{c}\mathrm{H} 0 \text { (/ H13): There is } \\
\text { independence (/ a relation) } \\
\text { between the mentor pool } \\
\text { size and a CA's success }\end{array}$ & Continuous (interval) & $\begin{array}{c}\text { Simple } \\
\text { logistic } \\
\text { regression } \\
\end{array}$ & $\begin{array}{c}\text { Point-Biserial } \\
\text { Correlation by } \\
\text { Pearson } \\
\end{array}$ \\
\hline Independent & $\begin{array}{c}\text { Mentor } \\
\text { selection } \\
\text { internal/ext } \\
\text { ernal } \\
\end{array}$ & $\begin{array}{c}\mathrm{H} 0 \text { (/ H14): There is } \\
\text { independence (/ a relation) } \\
\text { between the mentor source } \\
\text { and a CA's success }\end{array}$ & Categorical & Chi-Square & Cramer's V \\
\hline
\end{tabular}

\section{Results}

The results of the statistical analysis are summarized in Table 4. The table shows that out of the 14 tested potential success drivers 5 proved to have a significant correlation (marked in green). The reading should be done in the following manner, first the significance test should be taken into account as it indicates whether the results are statistically significant or can be disregarded as a mere coincidence. $95 \%$ confidence interval is used to access the results. In case that the significance test is passed, correlation should be analyzed. 
Table 4: Results of the statistical analysis of success drivers of corporate accelerators

\begin{tabular}{|c|c|c|c|c|}
\hline $\begin{array}{l}\text { Tested Success } \\
\text { Driver }\end{array}$ & $\begin{array}{c}\text { Significance } \\
\text { test }\end{array}$ & $\begin{array}{c}\text { Results to } \\
\text { significance } \\
\text { test }\end{array}$ & Correlation test & $\begin{array}{c}\text { Results to } \\
\text { correlation } \\
\text { test }\end{array}$ \\
\hline Successful & - & - & - & - \\
\hline $\begin{array}{l}\text { Prior knowledge } \\
\text { (CA's experience as } \\
\text { years in Operation) }\end{array}$ & $\begin{array}{c}\text { Simple } \\
\text { logistic } \\
\text { regression }\end{array}$ & 0,271 & $\begin{array}{c}\text { Point-Biserial } \\
\text { Correlation by } \\
\text { Pearson } \\
\end{array}$ & $-0,213$ \\
\hline $\begin{array}{l}\text { Industry focus related } \\
\text { to mother company } \\
\text { (clear vertical) }\end{array}$ & Chi-Square & 0,097 & Phi & $-0,314$ \\
\hline Program duration & $\begin{array}{c}\text { Simple } \\
\text { logistic } \\
\text { regression } \\
\end{array}$ & 0,962 & $\begin{array}{c}\text { Point-Biserial } \\
\text { Correlation by } \\
\text { Pearson } \\
\end{array}$ & $-0,087$ \\
\hline Portfolio size & $\begin{array}{l}\text { Simple } \\
\text { logistic } \\
\text { regression }\end{array}$ & 0,009 & $\begin{array}{c}\text { Point-Biserial } \\
\text { Correlation by } \\
\text { Pearson } \\
\end{array}$ & 0,490 \\
\hline Selection selectivity & $\begin{array}{l}\text { Simple } \\
\text { logistic } \\
\text { regression }\end{array}$ & 0,948 & $\begin{array}{c}\text { Point-Biserial } \\
\text { Correlation by } \\
\text { Pearson } \\
\end{array}$ & 0,014 \\
\hline $\begin{array}{c}\text { Selection Process } \\
\text { Type }\end{array}$ & Chi-Square & 0,018 & Cramer's V & 0,537 \\
\hline $\begin{array}{l}\text { CA's Team } \\
\text { Composition }\end{array}$ & Chi-Square & 0,335 & Cramer's V & 0,279 \\
\hline $\begin{array}{c}\text { Integration of success } \\
\text { metrics }\end{array}$ & Chi-Square & 0,008 & Phi & 0,501 \\
\hline $\begin{array}{l}\text { Support from top } \\
\text { management team }\end{array}$ & Chi-Square & 0,229 & Phi & $-0,227$ \\
\hline $\begin{array}{l}\text { Cooperation with } \\
\text { corporate partner(s) }\end{array}$ & Chi-Square & 0,021 & Phi & 0,436 \\
\hline $\begin{array}{c}\text { Existence of a scouting } \\
\text { team that actively } \\
\text { looks for start-ups }\end{array}$ & Chi-Square & 0,0215 & Cramer's V & 0,331 \\
\hline $\begin{array}{l}\text { Mandatory physical } \\
\text { presence for } \\
\text { participating start-ups }\end{array}$ & Chi-Square & 0,032 & Cramer's V & 0,496 \\
\hline Size of mentor pool & $\begin{array}{l}\text { Simple } \\
\text { logistic } \\
\text { regression }\end{array}$ & 0,418 & $\begin{array}{c}\text { Point-Biserial } \\
\text { Correlation by } \\
\text { Pearson }\end{array}$ & 0,205 \\
\hline $\begin{array}{l}\text { Mentor selection } \\
\text { internal/external }\end{array}$ & Chi-Square & 0,144 & Cramer's V & 0,372 \\
\hline
\end{tabular}

Following analysis interprets the test results of each potential success driver in detail. 
H1, prior years of knowledge: Many CAs advertise the experience they have built up over the years of running the CA program. The underlying assumption is that experience in the field will lead to improvements and eventually to better results. In order to examine this relation, the years in operation were calculated as time from launch date until today or until the date the CA was closed. Results show that no statistical significance could be found (sig. $=0,271>0,05$ ). Hence, the null hypothesis that the two variables are independent from each other cannot be rejected.

H2, clear vertical: By focusing on verticals, the CA can develop an expertise and reputation in the field. Yet, the Pearson Chi-Square test does not show a significant association between a clear vertical and a CA's performance. That is to say that the proportion of cases in each row of the contingency table (no clear vertical and clear vertical) does not significantly differ across the columns (not successful and successful). Chi - Square $(1, N=28)=3, p=.097$. Hence, the null hypothesis that the two variables are independent from each other cannot be rejected. The proportion of CAs with a clear vertical that were not successful is of $93,3 \%$ while the proportion of successful CAs with a clear vertical is $69,2 \%$. It appears that there might be a dependence between not having a clear vertical and being successful rather than the opposite. Furthermore, the negative phi coefficient of $-0,314$ also implies a negative correlation. However, given the lack of statistical significance, this effect of not having a clear vertical on a CA's performance cannot be confirmed.

H3, program duration: By extending the cycle time, the interconnection between corporate accelerator and the start-up increases. Yet, when analysing the relation between program duration and the CA's success, no statistically significant relationship could be validated. Results show significance level of 0,697 and that only $0,7 \%$ of the variation in the dependent variable "successful?" can be explained by the model. Therefore, the null hypothesis cannot be rejected. Out of the 13 successful CAs, $62 \%$ have a program duration that is 3 months or shorter and $38 \%$ do not (3x 4 months, 2x 6 months). From the 15 not successful CAs, 53\% offer programs with a duration of 3 months or shorter and $47 \%$ do not (1x 4 months, $2 x$ 5 months $4 \times 6$ months).

H4, portfolio size: An argument in favour of small batches is that the CA team and mentors can focus all their energy and concentration on a small, selected number of start-ups. A counterargument is that the bigger the batch more interactions with peers will participants have. Table 5 shows a positive relationship between the portfolio size and the CA's success as the significance level is 0,009 . Furthermore, table 5 shows that $48,7 \%$ of the dependent variable's variation can be explained by the model. Therefore, the null hypothesis is rejected, portfolio size and a CA's success are correlated in some way. To find out the direction and strength of this correlation a Point-Biserial Correlation by Pearson was applied. The Pearson correlation coefficient $r$ of 0,49 in table 6 represents a strong positive association. Hence, as the portfolio size increases the CA's success also increases. Despite this 
clear positive correlation, it should be considered that in general, it always depends on the capability to work with a certain number of start-ups simultaneously. If the program quality suffers by increasing the portfolio size, the CA's success will not be helped. But if the corporate accelerator has the resources and capabilities to host a bigger number of start-ups it should take the opportunity and do so.

Table 5: Statistical influence between portfolio size and success

\begin{tabular}{|c|c|c|c|c|c|c|c|}
\hline \multicolumn{7}{|c|}{ Variables in the equation } \\
\hline \multicolumn{2}{|c|}{} & B & S.E. & Wald & df & Sig. & $\operatorname{Exp}(\mathrm{B})$ \\
\hline \multirow{3}{*}{ Step 1a } & Portfolio size & 0.487 & 0.186 & 6.832 & 1 & 0.009 & 1.627 \\
\cline { 2 - 8 } & Constant & -3.949 & 1.526 & 6.696 & 1 & 0.009 & 0.019 \\
\hline \multicolumn{8}{|c|}{ Model Summary } \\
\hline \multirow{2}{*}{ Step 1 } & \multicolumn{2}{|c|}{ Log } & Cox \& Snell & Nagelkerke \\
\cline { 2 - 7 } & Likelihood & R Square & R Square \\
\cline { 2 - 7 } & 25.422 & 0.358 & 0.478 \\
\hline
\end{tabular}

Table 6: Statistical correlation between portfolio size and success

\begin{tabular}{|c|c|c|c|}
\hline \multicolumn{4}{|c|}{ Correlations } \\
\hline \multirow{3}{*}{ Succesful? } & Pearson Correlation & Succesful? & Portfolio Size \\
\cline { 2 - 4 } & Sig. (2-tailed) & 1 & 0.490 \\
\cline { 2 - 4 } & N & 28 & 0.009 \\
\hline
\end{tabular}

H5, selectivity: The average acceptance rate of this sample was $4,86 \%$ while the median was 3,15\% which are both below the threshold of 5\%. The significance level of 0,948 implies no statistical relationship and the Nagelkerke $R$ square value shows that $0 \%$ of the dependent variable's variation can be explained by the model. The next step was to test selection selectivity as bigger as or smaller than $5 \%$. Consequently, the data set turned into a categorical one and the data was categorised in three categories ( $>5 \%,<5 \%$ and N/I) allowing it to be tested with a Pearson ChiSquare test. Yet, the Pearson Chi-Square test did not indicate a statistically significant relationship either. Chi - Square $(1, \mathrm{~N}=28)=2, \mathrm{p}=.193$. As a result, the null hypothesis cannot be rejected.

H6, selection process type: The results of a program depend on the quality of applicants which can be influenced for example by the general value proposition and the program's set-up and conditions. It is also critical to spot and select the best start-ups out of a large number of applicants. The research of different corporate accelerator business models revealed that the selection process can be clustered in three different kinds:

1. An exclusive online application that is scanned by the selection team. 
2. An online application with a subsequent interview. A certain number of start-ups gets shortlisted and invited for a single interview (either via Zoom or live).

3. An online application with a subsequent selection event. This can last couple of days and contains several interviews, pitches, and other recruitment events. From the online applications, a certain number of start-ups gets shortlisted and invited to participate in the selection day where the selection team meets all start-ups in person throughout different situations.

Effort and costs are rising from option 1 to 3 . The question is whether additional input is rewarded by a better performance of the CA. According to the Pearson ChiSquare test, there is a significant relation between the selection process type and a CA's performance. Chi - Square $(2, \mathrm{~N}=28)=8, \mathrm{p}=.018$. Hence, the null hypothesis that there is independence between the two variables is rejected. The contingency table of the Chi-Square test also clearly shows the relationship. The relative frequency of CAs that integrate a selection day in their application process is $53,3 \%$ for those that are not successful but a full $100 \%$ for successful CAs. Consequently, implementing a more sophisticated selection process does have a positive effect on the CA's success. To test the strength and direction of this correlation Cramer's V correlation coefficient was tested since the categorical variable was not a binary one but had more than two options. The correlation coefficient of 0,537 can be interpreted as a strong positive association since Phi and Cramer's V measures are similar to the correlation coefficient in its interpretation. Hence, a more detailed selection process leads to higher results.

Table 7: Statistical influence of Selection Process on CA's success

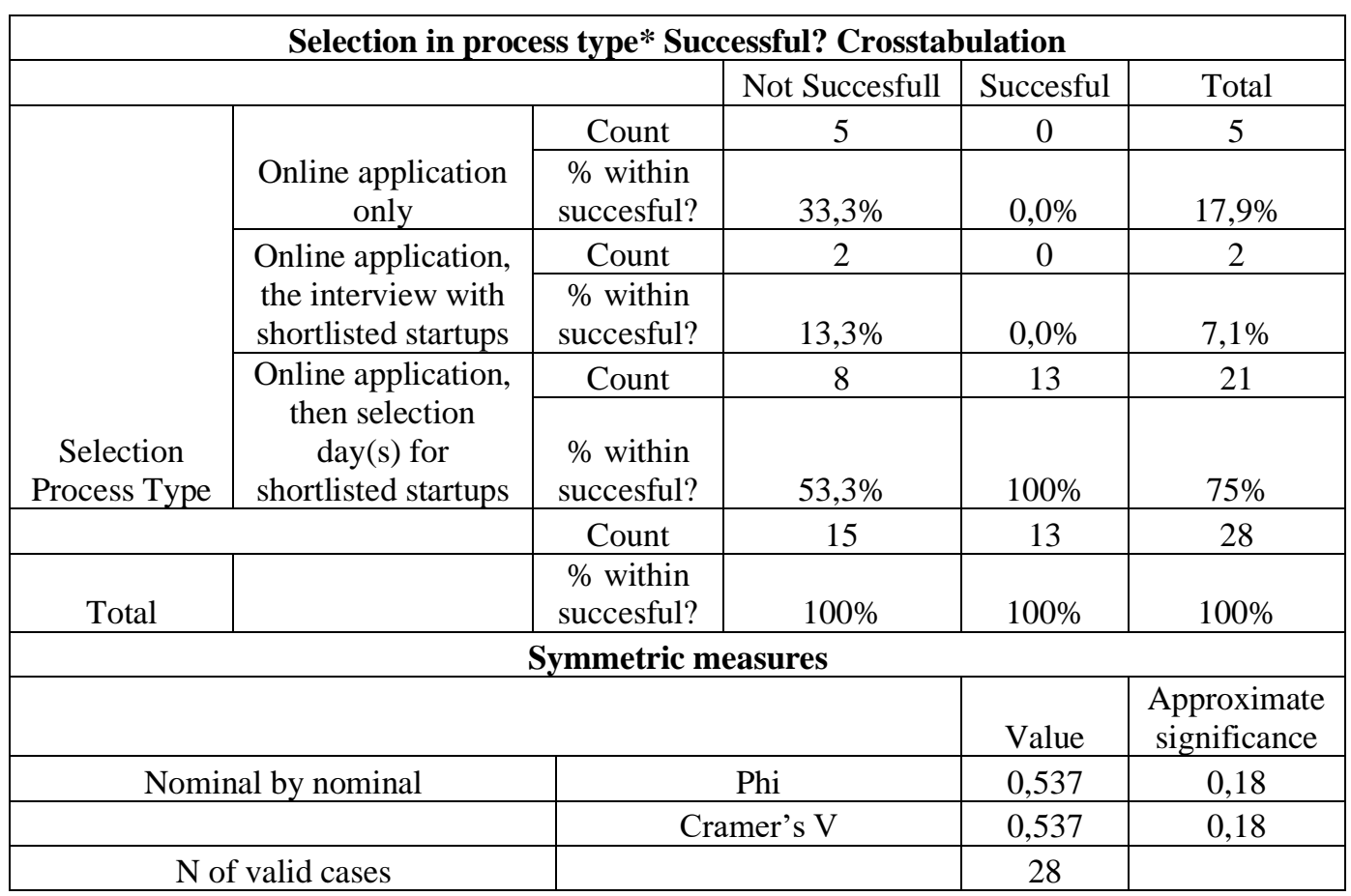


H7, CA's team composition: A CA's team structure is the backbone of management. In these teams there can be different roles like investment manager or program director. Even though all positions can affect success it is probably the leading managing director (MD) that is taking the most crucial decisions for the corporate accelerator's success. Hence, the focus was on the MD and his senior leadership team when examining team composition. This paper classified the CA team structures in internal, external and internal + external. Chi - Square $(2, \mathrm{~N}=$ $28)=2, p=.355$. The null hypothesis that there is independence between the two variables could not be rejected. Results show that the relative frequencies for CAs with pure internal or pure external team structures are bot higher for not successful CAs than for successful ones. Those CAs that consist of internal and external team members are the only case where the successful CAs $(46,2 \%)$ show a higher relative frequency than the not successful ones $(20 \%)$.

H8, incorporation of metrics: It is common business practice to use KPIs in order to measure goal achievement. However, in the acceleration industry it does not seem to be common standard yet. Only $18 \%$ of the 28 examined CAs publicly stated that they use success metrics to track their progress. Despite the uncommon usage, a statistically significant relation between the incorporation of metrics and a CA's success could be seen. Chi - Square $(1, N=28)=7, p=.008$. Thus, the null hypothesis could be rejected. The contingency table (Table 8) shows that the proportion for CAs that do not publicly state to incorporate metrics is $100 \%$ for those that are not successful and $61,5 \%$ for the successful ones. Meanwhile the proportion of CAs that use metrics and are not successful is $0 \%$ and that of CAs that use metrics and are successful is 38,5\%. To test the strength and direction of the correlation the Phi coefficient was applied since the contingency table is a $2 \times 2$ matrix. The value of 0,501 implies a strong positive association meaning the incorporation of metrics into the operation improves the performance. 
Table 8: Statistical influence of incorporated success metrics on CA's success

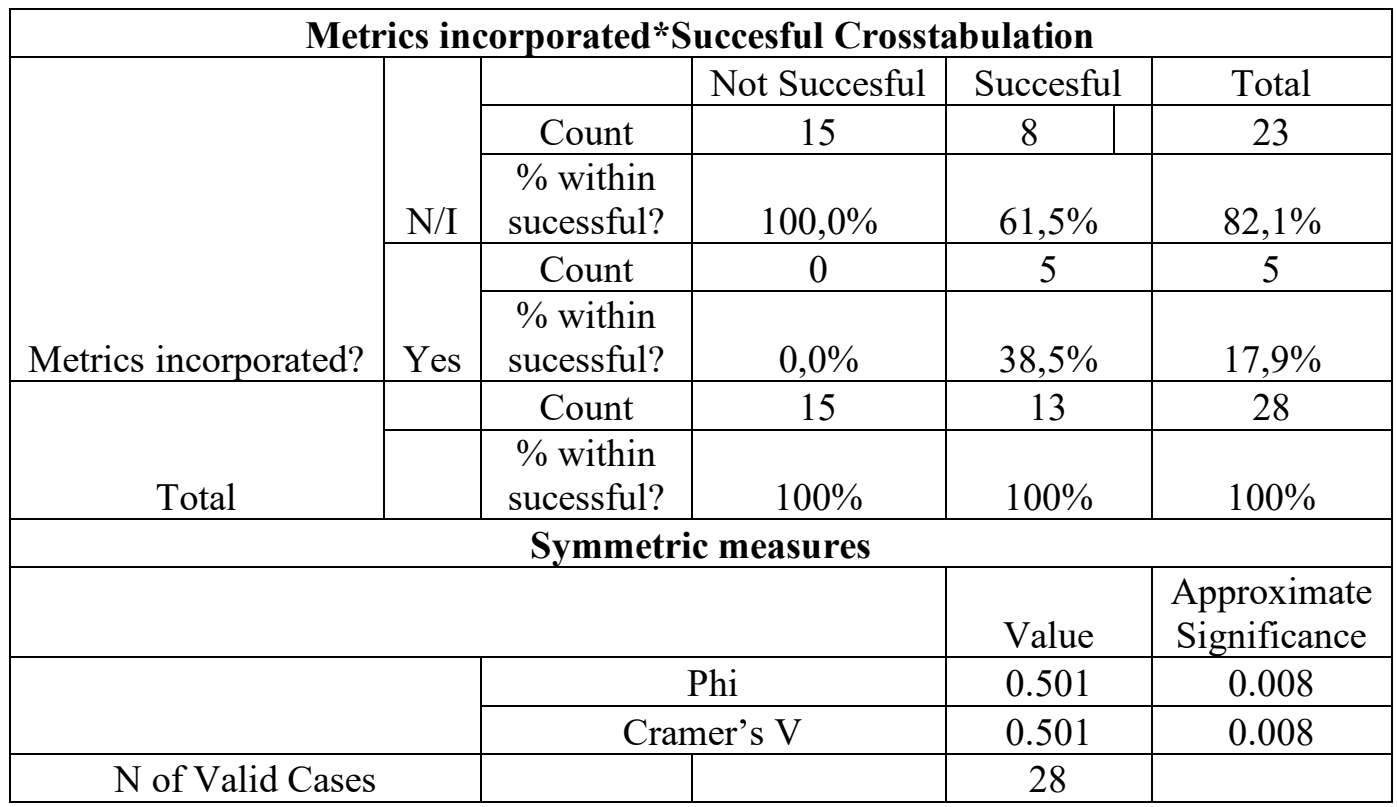

H9, support from top management: It is a logic conclusion that start-up teams will be more encouraged if they prepare for one-on-one sessions with a corporate's board members and that these board members make good mentors that increase the program quality. Since statements that say that top management support does not exist are very unlikely to be published, the two categories in which the examined CAs were classified were support and N/I. When testing the relationship of CAs that have the mother company's top management support and their performance, no statistically significant relation could be identified. Chi - Square $(1, N=28)=1, p$ $=.229$. As a result, the null hypothesis cannot be rejected.

H10, corporate partner: Researching the structures of different corporate accelerators, it became obvious that more and more cooperate with other firms that have similar objectives. This cooperation trend is a recent development and could not be observed in the same way in the past. Out of the 14 CAs that have partner, $21 \%$ (3) were founded before 2016 while $79 \%$ (11) were founded in 2016 or later. The trend of growing corporate cooperation becomes even clearer from the perspective that from the CAs that launched before 2016, $20 \%$ have a corporate partner while from those CAs that launched in 2016 or later, $85 \%$ have a corporate partner. Furthermore, out of those CAs that changed and reopened their business model, $100 \%$ started the new CA in cooperation with one or more corporate partners. For example, the Media-Saturn Group shut down their Spacelab in 2016 and opened Retailtech Hub in 2017. 
As the name indicates, this new CA business model is an open innovation platform for all corporates and start-ups connected to the retail industry. Axel Springer Plug and Play closed in 2018 and started a new CA in cooperation with Porsche Digital in 2019. Metro closed their retail-oriented CA in 2018 in order to open up a new CA in cooperation with the American retail chain Target in 2019. Seeing this clear trend towards corporate cooperation, the question was whether CAs that engage in these kinds of cooperation are more successful than those that do not. The Pearson Chi-Square test shows that there is a statistically significant relation between the cooperation with corporate partners and a CA's success, therefore the null hypothesis is rejected. Chi - Square $(1, \mathrm{~N}=28)=5, \mathrm{p}=.021$. The contingency table (Table 9) shows the details of this correlation. The proportions for CAs that have no corporate partner and are not successful is $66,7 \%$ while the proportion of CAs without a corporate partner and with success is $23,1 \%$.Simultaneously, the proportion of CAs that do have a cooperation with other corporates and are not successful is $33,3 \%$ while the proportion of CAs with corporate cooperation and success is $76,9 \%$. Furthermore, the Phi coefficient of 0,436 indicates a reasonable positive association. One can conclude, that having a corporate partner does have a positive effect on a CA's performance.

Table 9: Statistical influence of corporate partners on CA's success

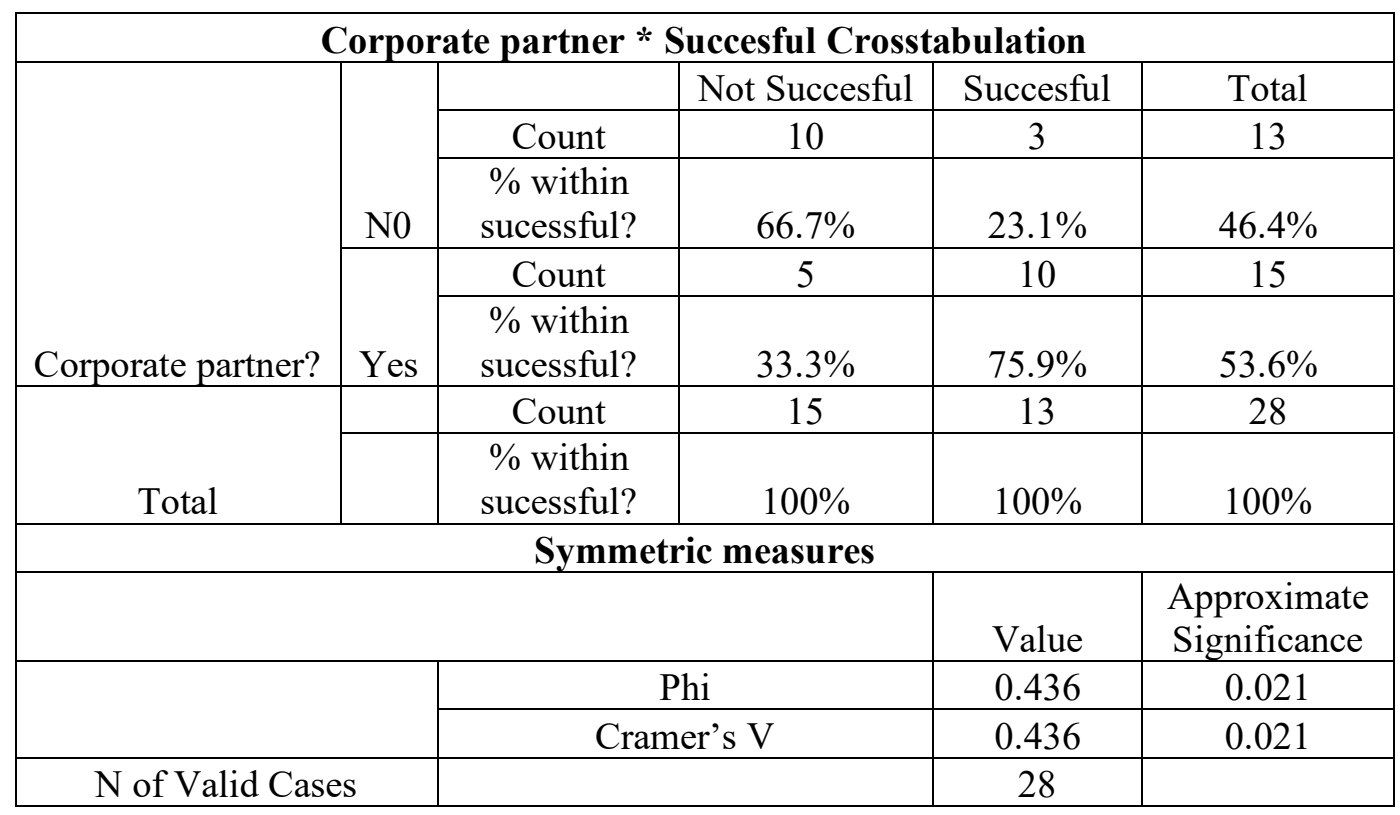

H11, scouting team: Certain corporate accelerators installed specific teams whose job was to actively look for start-ups that might fit to the program. These teams would visit conferences related to the start-up industry or the CA's target industry or attend similar networking events in order to promote the CA to potential applicants. A potential consequence could be that the number and quality of 
applicants rises which could have a positive effect on the general performance. The Pearson Chi-Square's significance level of 0,215 implies that such a relation is not statistically proven. Chi - Square $(2, N=28)=3, p=.215$. Consequently, the null hypothesis cannot be rejected.

H12, mandatory physical presence: Some of the examined CAs promoted that fact that physical presence is not mandatory to be part of the program. This could either have a positive or a negative effect on the performance. Not having to move to a specific town for 3 months gives more freedom to the participating start-ups. A positive effect could therefore be that more and better start-ups apply to the program and this increase in quantity and quality improves the CA's performance. Yet, the lack of physical interrelations on a daily basis could also lead to a decrease of the outcome quality. There is a statistically significant relation between the obligation to be present and a CA's success, hence the null hypothesis is rejected. Chi - Square $(2, \mathrm{~N}=28)=7, \mathrm{p}=.032$. While the proportions for CAs that do not require physical presence are relatively similar, the proportions for CAs that require physical presence are $40 \%$ for not successful CAs and $76,9 \%$ for successful ones. Consequently, there is a positive relation between obligating start-ups to move in the CA's premises and the CA's success. This strong positive correlation was also confirmed by Cramer's V coefficient of 0,496. 
Table 10: Statistical influence of mandatory physical presence on CA's success

\begin{tabular}{|c|c|c|c|c|c|}
\hline \multicolumn{6}{|c|}{ Mandatory physical presence * Succesful Crosstabulation } \\
\hline \multirow{5}{*}{$\begin{array}{l}\text { Mandatory physical } \\
\text { presence }\end{array}$} & \multirow[b]{3}{*}{ N/I } & & $\begin{array}{c}\text { Not } \\
\text { Succesful }\end{array}$ & Succesful & Total \\
\hline & & Count & 3 & 3 & 6 \\
\hline & & $\begin{array}{c}\% \text { within } \\
\text { sucessful? }\end{array}$ & $20.0 \%$ & $23.1 \%$ & $21.4 \%$ \\
\hline & \multirow[b]{2}{*}{ Yes } & Count & 6 & 10 & 16 \\
\hline & & $\begin{array}{c}\% \text { within } \\
\text { sucessful? }\end{array}$ & $40.0 \%$ & $76.9 \%$ & $57.1 \%$ \\
\hline \multirow[b]{4}{*}{ Total } & \multirow[b]{2}{*}{ No } & Count & 6 & 0 & 6 \\
\hline & & $\begin{array}{c}\% \text { within } \\
\text { sucessful? }\end{array}$ & $40.0 \%$ & $0.0 \%$ & $21.4 \%$ \\
\hline & & Count & 15 & 13 & 28 \\
\hline & & $\begin{array}{c}\text { \% within } \\
\text { sucessful? }\end{array}$ & $100 \%$ & $100 \%$ & $100 \%$ \\
\hline \multicolumn{6}{|c|}{ Symmetric measures } \\
\hline & & & & Value & $\begin{array}{l}\text { Approximate } \\
\text { Significance }\end{array}$ \\
\hline & & \multicolumn{2}{|c|}{ Phi } & 0.496 & 0.032 \\
\hline & & \multirow{2}{*}{\multicolumn{2}{|c|}{ Cramer's V }} & 0.496 & 0.032 \\
\hline $\mathrm{N}$ of Valid Case & & & & 28 & \\
\hline
\end{tabular}

H13, mentor pool size: The research of different CA business models revealed that the mentor pool size varies strongly. The average mentor pool size of this sample is 129 while the median is 110 but the range of this study's sample goes from 2 to 300 . This brought up the question whether it is more effective to work with a small group of mentors or with a bigger pool of mentors. The significance level of 0,418 shows that there is no significant relation between the size of the mentor pool and a CA's success meaning that the null hypothesis cannot be rejected.

H14, mentor source: Mentors play an important role in the business model. How does a corporate acceletator select the right mentors for its program? To ensure a lean and clear research process, this study differentiates internal, external and internal + external mentors. Yet, this examined sample did not show a statistically relevant relation between the type of mentor source and a CA's success. Chi Square $(2, \mathrm{~N}=28)=4, \mathrm{p}=.144$. Hence, the null hypothesis cannot be rejected. 


\section{Discussion}

Which are the drivers of a corporate accelerator's success? Are there certain characteristics successful corporate acceleration programs share? If so, are there specific factors that should be prioritized? Also, what could be an explanation for the factors that show significant influence on a CA's success?

\subsection{Characteristics that have shown a strong correlation to success (highly considerable)}

The findings contain five success factors that showed statistical significant correlation to a CA's success. These five categories should receive special attention from managers when developing the business model, here they will be labelled as "prerequirements" for a successful corporate accelerator:

Selection process: Our findings indicate that CAs should invest in their selection process and set up a two-step application process consisting of an online application and a subsequent invitation to selection day(s) for shortlisted start-ups. A first potential reason is that an intensive selection day allows the CA team to better know the candidates and gives the CA an opportunity to assess and differentiate between candidates who at a glance seem very similar. Many CAs state that the team is a crucial selection criterion. In the selection days the representatives can test the team in different situations (also when they are not aware of being assessed). This facilitates the assessment of the team's performance and also helps predict future performance. Furthermore, teams can be compared simultaneously rather than one after the other. A specific point that cannot be tested in an online application are different soft skills. For start-ups, it is crucial to sell themselves and their ideas in order to convince investors. The selection day gives the perfect opportunity to test and assess these skills. A second major advantage apart from the improved evaluation potential is the employer branding perspective. Throughout the selection day, CAs cannot only chose the right start-ups but also impress them and convince them to join the program.

Incorporation of metrics: [20] Dempwolf et al. (2014), [21] Haines (2014) and Kanbach and Stubner (2016) all stress the importance of the incorporation of metrics to track progress of start-ups as well as the achievement of a (corporate) accelerator's objectives. Our findings show that CAs should install KPIs that measure the start-ups development process as well as the CA's own goals. Metrics can help to track the progress of the start-ups and of the program benefitting both parties. In general, success metrics can be separated into forward and backwardlooking metrics. Forward looking metrics improve the expectation management. Participating start-ups, but also for example CA employees, have clarity regarding their performance expectations. Backward looking metrics help with the assessment of result and performance. These quantifiable results for different business areas could potentially make it easier to recognize red flags in time and take the needed 
measures. Metrics generally serve to take informed decisions, but they can for example also be used to hold people accountable for their performance.

Mandatory physical presence: Our findings show that physical closeness improves the outcome. A deeper analysis holds several potential explanations. First, and maybe most importantly, the work in the same facilities has a great potential to create a highly motivating environment. Start-ups are constantly surrounded by CA employees, mentors and especially other start-ups. Various alumni state that one of the biggest learnings came from working with other teams. Being in the same room fosters an environment of cooperation that can help the overall program outcome. Second, the frequency of interaction, especially spontaneous ones, drastically increases. It is commonly said that the best ideas and conversations happen in the cafeteria. Third, the physical presence gives the CA managers greater monitoring and control possibilities. They can constantly oversee the start-up's progress and intervene at the right time if needed. Lastly, physical closeness minimizes misunderstandings that can derive from communication gaps. Yet, it might make sense for CAs to find a hybrid version between freedom of operation for start-ups and physical closeness to not jeopardize the start-ups' creativity and especially in post covid era. For instance, accelerators could (i) set a general standard for startups to work in the CA's facilities, (ii) require mandatory physical presence for key meetings but (iii) offer a certain level of flexibility to work remotely.

Corporate partner: A general trend in the CA industry can be observed: more and more CAs partner up with other corporations. Also, in our sample, the amount of CAs that have a corporate partner is $50 \%$. More importantly, our findings show a significant positive relation between having corporate partner(s) and a CA's success. There are several potential explanations for this phenomenon. First, having a corporate partner means sharing the risk as well as the financing cost of the program. Second, corporates can benefit from each other's knowhow, reputation and standing. The risk of partnering is that after the program, start-ups might choose to work with the corporate partner instead of one's own mother company. Yet, the fear of competition seems to have been outweighed lately by the benefits of setting up an open ecosystem.

Batch size: Our findings show that CAs should increase their batch size if they have the required human capital, financial resources and knowledge to guide a bigger batch of participating start-ups. Kim and Wagman (2014) published that finding the right start-up portfolio size (number of companies in an accelerator program) is crucial for an accelerator's success. By increasing the batch size, they have a bigger exposure to ideas that might fit what the accelerator is looking for. However, the quality of the program should never suffer by increasing the batch size. The biggest batch size of our sample is that of Daimler's Startupautobahn which hosts 34 startups per batch. The next biggest CAs are the Airbus BizLab with 20 and APX and Axel Springer Plug and Play with 12 each. Daimler manages to maintain high 
quality standards despite the big number of start-ups per batch because the automotive company cooperates with 27 other corporates when organizing its program. Analysing the relationship between bigger batch sizes and success, one should keep in mind the difference between correlation and causation. Applied to this case, the data shows that CAs with bigger batch sizes are more successful. Yet, this does not automatically mean that it is the bigger batch size that led to the success. Maybe, successful CAs simply tend to increase their batch size.

\subsection{Additional characteristics to be considered (optional)}

In addition to the five statistically significant success factors, there are other success factors that did not turn out to be significant but that CAs should still keep in mind when setting up their business model.

CA team composition: According to the data, it does not influence a CA's success whether the CA's team composition is internal, external or a mixture of both. Yet, this factor should not be completely disregarded. Even if not statistically validated, our analysis shows a trend that CAs with mixed teams are more successful. A potential explanation could be that a CA needs staff (and especially leadership) that has experience in the start-up world but also understands the structures and procedures within the organization in order to represent the interests to the mother company. This combination can be reached by setting up a mixed team of externals with entrepreneurial background and internals that are industry experts and know the organization. Naturally, the balancing act of entrepreneurial and corporate experience can also be managed in other ways. Internals can have entrepreneurial experience and externals can be familiarized with the company's organizational structures. What matters is that both areas are covered not how they are covered.

Mentor source: The data did not reveal statistical dependence between the mentor source and success. Yet, mentors need to cover a broad field of expertise and it is hard to find all the required expertise within the own company. Therefore, it is likely that internal mentors are experts in the field/industry but for specific start-up related questions external expertise is required.

Support from top management: Kanbach and Stubner (2016) name support and commitment as well as access to the mother company's management board and top management team as a critical success factor. They state that "top management support increases the credibility and acceptance of the program within the entire organization" and will increase the encouragement and engagement from employees within the firm. Our dataset shows no direct statistically significant dependence between the support from the top management and a CA's success. Yet, despite not being statistically significant, our analysis indicates that CAs that receive top management's support perform better than those who do not. A reason for the missing significance could be that top management support is potentially 
more relevant for some CA types than for others. Top management support could, for example, be more relevant for corporate accelerators which depend on business units integrating the start-ups' new solutions into the corporate's value chain. To enable a seamless integration, the right employees need to be familiar with the startups' developments which requires an active participation and acknowledgement of the CA from all employees. For others, with goals less interlinked with those of the mother company, top management support might not be as essential. Board members would still make effective mentors of the CA program but the effect of motivating the mother company's employees could have less importance in this case.

Scouting team: The data analysis did not reveal any statistically significant correlation between the existence of a scouting team that actively looks for startups and a CA's success. Yet, in specific cases the existence of a scouting team may be the right step. Kanbach \& Stubner (2016) mention in their study that "networking (at events and start-up conferences and with venture capitalists) identifies and attracts promising start-ups". The scouting team could for example be especially helpful if a CA needs more high-quality applications. By scanning the market, the team could contact interesting start-ups that otherwise might not have applied to the program.

Selectivity: The data set revealed statistical independence between the selectivity and a CA's success. Yet, Baird, Bowles and Lall (2013) argue that a high degree of selectivity, in form of an acceptance rate of $<5 \%$ increases the success of independent accelerators. Regardless of statistical significance, the dataset indicates that CAs that meet the goal are more successful than those who do not. There could be several explanations for these increased success rates. A first reason is that greater selectivity keeps the standard of the class high.

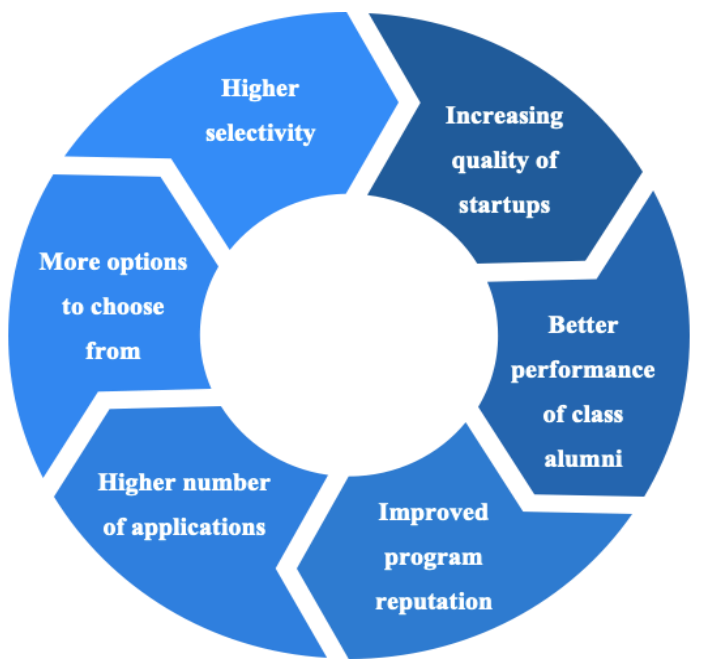

Figure 1: The Selectivity cycle 
The overall quality of participating start-ups increases with a higher selectivity which leads to a better performance of the class as alumni. This improves the program's reputation which leads to higher application numbers. In general, the number of applications matters because it gives the CA more options to choose from (see figure 1). The goal should therefore also be to increase the number of applications and then select a reduced number of start-ups. Second reason why selectivity matters is that there is a marketing effect of highly selective programs.

\subsection{Examined success factors that have no effect and can be de-prioritized}

Finally, there is a set of success factors that did not show a significant correlation to success and that CA managers can deprioritize when setting up a program.

Prior years of knowledge: We could not find a statistically significant correlation between the amount of previous years of knowledge and success. However, this lack of significant correlation could have another reason. Experience in raising startups and especially in designing CA programs can certainly have a value in taking the right decisions. Yet, what matters to gain this experience is not necessarily the number of years that a CA has existed. Nowadays, the needed experience can be gathered by hiring the right people that bring this experience. The managers could have gained experience in previous jobs that they can now leverage for their current employer.

Clear vertical: The data shows that a clear vertical does not improve a CA's performance. It cannot be generalized that all accelerators should focus on a specific technological or industrial vertical. While Value Chain Investors should have a clear vertical by definition, some specific CAs, called Unicorn Hunters because they mainly pursue financial objectives (Kanbach and Stubner, 2016), can keep the spectrum broader to not miss an opportunity. However, some sort of restriction can be seen. APX for example only accepts "digital start-ups with an interest in the German or the US market" while the ProSiebenSat.1 Accelerator focuses on "B2C start-ups offering mass market relevant products or services".

Program duration: Previous studies stress the fact that CA programs have to be kept concise. Yet, we could not find a significant dependency between program duration and a CA's success. A possible explanation might be that a concise CA program is usually defined as 3-6 months but none of the CA programs that we examined were longer than 6 months. Hence, it might not be relevant whether a CA program is 3 or 6 months long but whether it is shorter than 6 months or not. 
Mentor pool size: The data shows no significance between the mentor pool size and a CA's success. The right size of the mentor pool has to be tailored to the general design of the CA. A small set of mentors might be beneficial if:

- The mentors have a very broad set of knowledge and expertise (start-up-generalists) or

- The participating start-ups have a very narrow industry and technology focus that requires knowledge only from a very specific area of expertise.

On the other site, a bigger mentor pool allows for more specialized experts and a potentially broader set of specialized experts.

\section{Conclusion}

The results of this study have a special impact on corporate accelerator managers, on managers of the mother companies and on entrepreneurs.

CA managers benefit from this study in several ways. First, they get an overview and inspiration of the various design options for CAs. Second, they can compare their own activities as well as the design of their program to those of competitors. Third, the findings of this study tell them on which fields they should focus in order to increase the chances of success and which fields might be deprioritized. Corporations benefit from this study in two ways. First, if they already run a similar program, this study allows them to evaluate whether the accelerator business model still matches the overall company strategy or whether a different type might be more applicable and evaluate whether a CA in general still matches the overall company strategy or whether a different type of corporate venturing might be more applicable. Second, if they plan to launch an acceleration program, this study helps them to pick the type of CA that matches their objectives best and get an idea of the various design possibilities and subsequently design the $\mathrm{CA}$ in a way that promises higher success. Lastly, start-ups benefit from this study in several ways. First, they get access to a database of existing CAs that they can potentially apply to. Second, the database gives them an overview of the characteristics of those CAs and whether they match what the start-up is looking for.

One of the main takeaways from the study is that there are multiple aspects of corporate accelerators which are commonly thought to be of high importance, yet some of them have no scientific proof and consequently could be disregarded. This is the case of years of prior experience, mentor pool size and having a clear vertical which as usually topics that corporate accelerators advertise on, thinking that they can represent a competitive advantage when attracting startups. However, as the data shows there is no correlation to success.

Obviously, the most significant conclusion which is both relevant for practitioners and researchers alike are the success criteria that showed positive correlation to the success of corporate accelerators. Those are: 1. existence of corporate partners , 2 . demanding selection process that contains selection days for shortlisted start-ups, 3 . larger amount of start-ups per batch, 4. obligation for start-ups to be physically present in the facilities for the time of the program (Pre Covid19) and finally 
5.incorporation of metrics to track the progress of participating start-ups. Penultimate point of mandatory physical presence could be a great starting point for further research as the methodologies and technologies for virtual working and collaboration improved significantly during Covid19 and it could be insightful to compare efficiency and success rates of companies taking part in virtual accelerators pre and post Covid. One of the notable examples could be Y Combinator, one of the most success independent accelerators which was known for offering exclusively on premise programs, however both summer and winter batches on 2020 were conducted online.

\section{Acknowledgements}

We thank all corporate accelerators for sharing their information, Sirine Douhane for having compiled this paper, Johan Ortiz, Yannis Pierrakis (Asociate Professor at Universitat Internacional de Catalunya) and Anna Akhmedova (Postdoctoral Researcher at IESE Business School), for their assistance and support.

Consent to participate: The authors of this paper give our consent for the participation of those who wish to contribute relevant documentation to this scientific document.

\section{References}

[1] MM1 Dax 30 startup- und innovationsmonitor (2019) DAX 30 Companies: Startup and innovation programs

[2] Schumpeter, J. A. (1942). Capitalism, socialism and democracy (2nd ed.). Floyd, Virginia: Impact Books

[3] Weiblen, T., \& Chesbrough, H. W. (2015). Engaging with Start-ups to Enhance Corporate Innovation. California Management Review, 57(2), 66-90.

[4] Bonzom, A., Netessine, S. (2016). How do the world's biggest companies deal with the Startup Revolution?

[5] Clarysse, B., \& Yusubova, A. (2014). Success factors of business accelerators. Technology Business Incubation Mechanisms and Sustainable Regional Development, Proceedings. Presented at the Technology Business Incubation Mechanisms and Sustainable Regional Development.

[6] Heinemann, F. (2015). Corporate accelerators: A study on prevalence, sponsorship, and strategy (Doctoral dissertation, Massachusetts Institute of Technology).

[7] Hochberg, Y. (2015). Accelerating Entrepreneurs and Ecosystems: The Seed Accelerator Model.

[8] Kohler, T., (2016). Corporate accelerators: building bridges between corporations and start-ups. Bus. Horiz. 59 (3), 347-357.

[9] Desai, V. M. (2016). The behavioral theory of the (governed) firm: Corporate board influences on organizations' responses to performance shortfalls. Academy of Management Journal, 59(3), 860-879. 
[10] Shankar, R. K., \& Shepherd, D. A. (2019). Accelerating strategic fit or venture emergence: Different paths adopted by corporate accelerators. Journal of Business Venturing, 34(5), 105886.

[11] Cohen, S., \& Hochberg, Y. V. (2014). Accelerating startups: The seed accelerator phenomenon.

[12] Hoffmann, D. L., \& Radojevich-Kelley, N. (2012). Analysis of Accelerator Companies: An Exploratory Case Study of Their Programs, Processes, and Early Results. Small Business Institute Journal, 8(2), 54-70.

[13] Kim, J. \& Wagman, L. (2014). Portfolio Size and Information Disclosure: An Analysis of Startup Accelerators.

[14] Malek, K., Maine, E., \& McCarthy, I. P. (2014). A typology of clean technology commercialization accelerators. Journal of Engineering and Technology Management, 32, 26-39.

[15] Kanbach, D.K., Stubner, S. (2016). Corporate accelerators as recent form of start-up engagement: the what, the why, and the how. J. Appl. Bus. Res. 32 (6), 1761-1776.

[16] Smith, S. W., \& Hannigan, T. J. (2015). Swinging for the fences: How do top accelerators impact the trajectories of new ventures. Druid, 15, 15-17.

[17] Cohen, S. L., Bingham, C. B., \& Hallen, B. L. (2019). The role of accelerator designs in mitigating bounded rationality in new ventures. Administrative Science Quarterly, 64(4), 810-854.

[18] Cohen, S. L., Bingham, C. B., \& Hallen, B. L. (2017). Why are some accelerators more effective? Bounded rationality and venture development. In Academy of Management Proceedings (Vol. 2017, No. 1, p. 11946). Briarcliff Manor, NY

[19] Baird, R., Bowles, L., \& Lall, S. (2013). Bridging the "Pioneer Gap". The Role of Accelerators in. 10510: Academy of Management.

[20] Dempwolf, C. S., Auer, J. and D'lppolito, M. (2014). Innovation Accelerators: Defining Characteristics Among Startup Assistance Organizations. Small Business Administration, Office of Advocacy.

[21] Haines, J. K. (2014). 'Iterating an Innovation Model: Challenges and Opportunities in Adapting Accelerator Practices in Evolving Ecosystems.' In Ethnographic Praxis in Industry Conference Proceedings. Wiley Online Library, pp. 282-295. 